\title{
外転神経麻痺を呈した急性蝶形骨洞炎例
}

\author{
加藤 明子 ·上田 成久 ・塩盛 輝夫 \\ 大淵 豊明・藤村 武之・鈴木 秀明
}

\section{Acute Sphenoid Sinusitis Associated with Abducens Nerve Palsy}

\author{
Akiko Katoh, Narihisa Ueda, Teruo Shiomori, \\ Toyoaki Ohbuchi, Takeyuki Fujimura and Hideaki Suzuki \\ (University of Occupational and Environmental Health, School of Medicine)
}

\begin{abstract}
Because the sphenoid sinus is adjacent to important structures including optic, oculomotor, trochlear, trigeminal, and abducens nerves, diseases of this sinus may cause related neurological disorders. We herein report a case of sphenoid sinusitis associated with abducens nerve palsy. A 66-year-old man with a 7-day history of diplopia was referred to our hospital. On physical examinations, he manifested left-sided abducens nerve palsy and nasal polyposis. Computed tomography and magnetic resonance imaging (MRI) demonstrated ethmoid-sphenoid sinusitis on the affected side. The patient underwent endoscopic sinus surgery on the day of examination followed by intravenous administration of hydrocortisone $(200 \mathrm{mg} /$ day for 3 days). Postoperative MRI showed a contrast-enhanced area in the left cavernous sinus, suggesting the presence of an inflammatory change. His postoperative clinical course was uneventful, and complete neurological recovery was obtained two and a half months after surgery. It is stressed that physicians should be aware of potential diseases of the sphenoid sinus during the diagnosis and management of such patients.
\end{abstract}

Key words : sphenoid sinusitis, abducens nerve palsy, cavernous sinus

\section{はじめに}

解剖学的に蝶形骨洞の前方には篩骨洞，後方にはトル コ鞍，下方には鼻咽腔，外方には視束管，上眼窩裂，海 綿静脈洞おうび内頸動脈が隣接している，そのため，蝶 形骨洞に生じた病変はさまざまな症状を起こしうること が知られている11.

なかでも蝶形骨洞のすぐ外側に隣接する海綿静脈洞の 内部には, 動眼, 滑車, 外転, 三叉神経が存在するため, 蝶形骨洞病変の洞外進展に伴い複視, 眼瞼下垂, 視力障 害といった神経眼科学的症状が高頻度に出現する ${ }^{2)}$.

今回，われわれは左外転神経麻痺を呈した急性蝶形骨 洞炎の 1 症例を経験したので, 若干の文献的考察を加え
て報告する．

症 例
症例 : 66 歳, 男性.
主訴: 複視.
現病歴: 2006 年 8 月 10 日から複視と頭痛に気づき, 同
日近医眼科および近医脳神経外科を受診したが, 原因が
わからなかった. 8 月 13 日に, 複視が増悪したため, 再
度別の眼科医院を受診し, 8 月 14 日に某総合病院脳神経
外科を紹介された. MRI にて精査した結果頭蓋内に異常
所見はなかったが, 副鼻腔炎を指摘された. 8 月 16 日に
同院耳鼻咽喉科を紹介され, 急性蝶形骨洞炎と診断され,




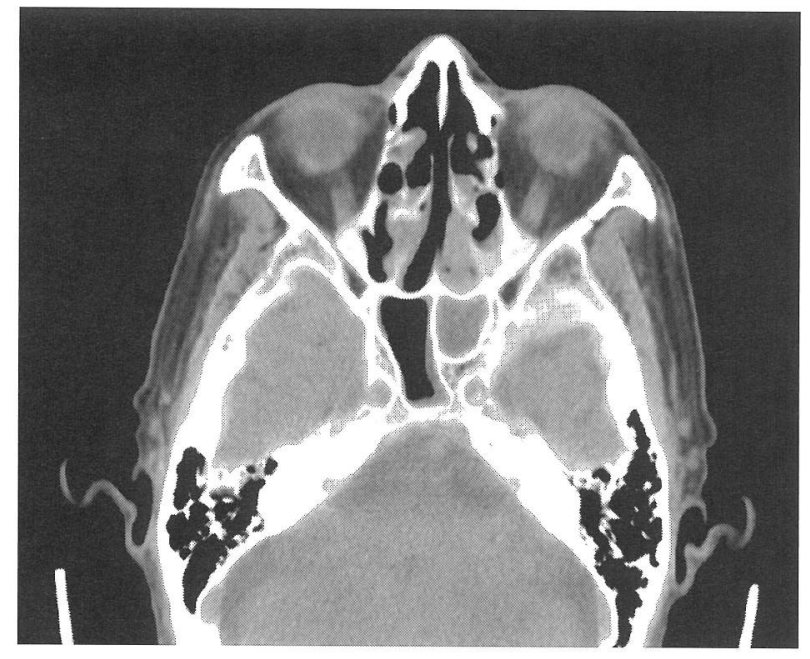

a

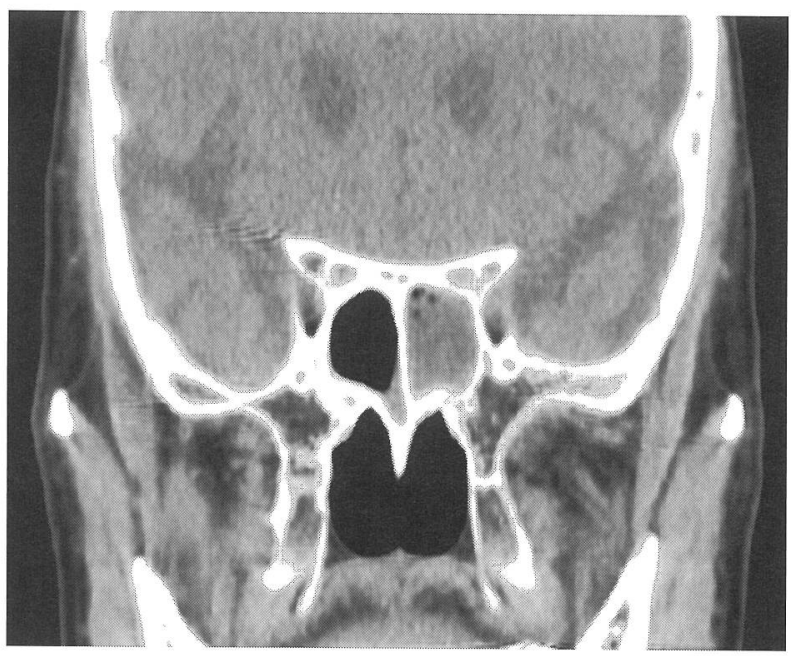

図 1 初診時 CT 所見（a. 軸位断，b。冠状断）

左後部篩骨洞から左蝶形骨洞に骨破壊を伴わない陰影が認められる.

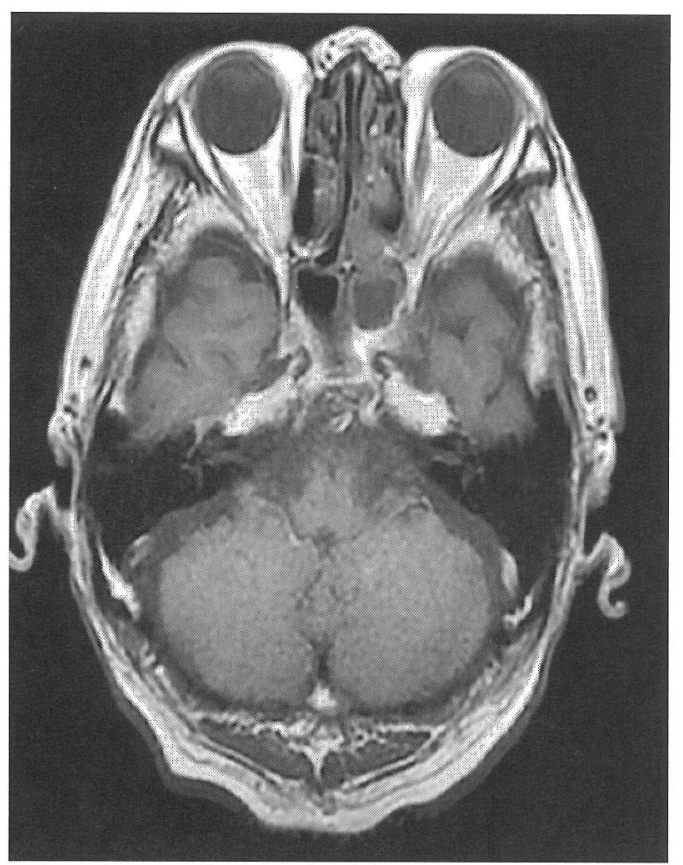

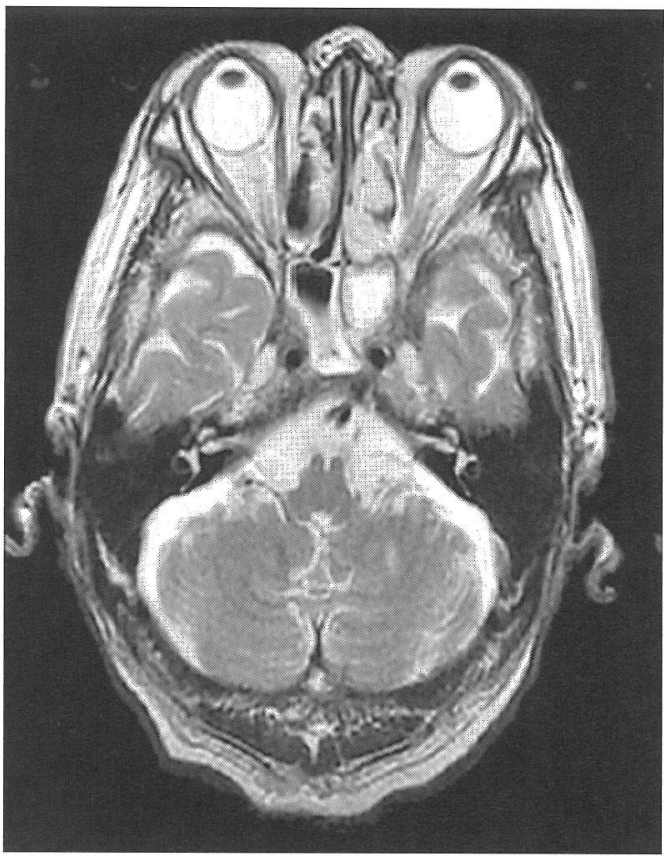

b

図 2 初診時 MRI 所見（a. T1 強調像，b. T2 強調像）

左後部篩骨洞から左蝶形骨洞に T1 強調画像で低信号, T2 強調画像で高信号に描出される陰影が認められる.

加療目的にて 8 月 17 日当科紹介受診となった。

既往歴： 40 年前, 両側上顎洞根本術。

初診時所見: 左中鼻道に鼻茸が充満しており, 膿性鼻
汁および後鼻漏が認められた。また左に凸の鼻中隔弯曲 症があった。視力・視野に異常なく, 瞳孔不同もなく, 対光反射も正常であった。眼位は両側とも正中であった 
が，左眼の外転障害が認められた。発熱はなかった。

血液所見 (初診時) : WBC $9900 / \mu 1, R B C 349$ 万 $/ \mu 1$, $\mathrm{Hb} 12.4 \mathrm{~g} / \mathrm{dl}$, Plt 183 万/ $\mu \mathrm{l}$, AST $34 \mathrm{IU} / 1$, ALT $47 \mathrm{IU} / \mathrm{l}$, BUN $10 \mathrm{mg} / \mathrm{dl}$, Cre $0.7 \mathrm{mg} / \mathrm{dl}, \quad$ CRP $0.12 \mathrm{mg} / \mathrm{dl}$

画像所見：副鼻腔 CT では両側の上顎洞は根本術後で あり，左後部節骨洞汃ら左蝶形骨洞に骨破壊を伴わない 陰影が認められた（図 1)。この陰影はMRIでは T1 強調 画像で低信号, T2 強調画像で高信号に描出さ机た。なお 頭蓋内に病変は認めら扎なかった（図2）。

経過: 紹介当日の 8 月 17 日, 急性蝶形骨洞炎の診断下 に内視鏡下鼻副鼻腔手術を施行した。まず鼻中隔矯正術 を施行し, その後, 篩骨洞を開放し, 経篩骨洞的に蝶形 骨洞を開放した。蝶形骨洞自然孔は膜性に閉鎖しており, 洞内は浮腫状粘膜と粘稠な膿汁で充満していた。これを 可及的に清掃除去し, 蝶形骨洞を十分開放して手術操作 を終えた。膿汁を細菌培養検査に提出したが, 菌の発育 は認めなかった。手術当日よりハイドロコルチゾン $200 \mathrm{mg}$ およびセフピロム $2 \mathrm{~g}$ の点滴静注を 3 日間施行し たが，外転神経麻疩はほとんど改善せず，複視も残存し たまま，術後 7 日目に退院となった。その後外来にてク ラリスロマイシン $200 \mathrm{mg} /$ 日を内服しながら経過観察を 行っていたが，9月 26 日の MRI では海綿静脈洞付近に $\mathrm{T} 1$ 强調画像で低信号, T2 強調画像で高信号, ガドリニウ ム造影で増強される炎症所見があり (図 3), 複視む残存
したままであった. 10 月中旬ごろより複視の改善が認め られ，10月 31 日には複視は消失し，神経学的にも外転 神経麻癭は全快した。

\section{考 察}

蝶形骨洞は解剖学的に視神経, 動眼神経, 滑車神経, 外転神経, 内頸動脈, 海綿静脈洞などと近接しているた めに, 蝶形骨洞内に炎症が生じるとこれらの神経, 血管 が障害されることがある314)。

蝶形骨洞炎の主訴では頭痛が最も多く, その出現率は $70 \sim 90 \%$ と高頻度である. 次いで視器症状が多く, 23.2 ～50.0\%と報告されている5) 7). なかでも，外転神経 麻痺が最多であり ${ }^{6)}$, これは解剖学的に海綿静脈洞の最 も内側に外転神経が走行しており，蝶形骨洞病変の影響 を受けやすいためと考えられている。 その他顔面痛や眼 窩後部痛が主訴となることも多い8). 本症例でも頭痛と， 外転神経麻痺による複視が認められた。

これに対し鼻閉, 膿性鼻汁, 後鼻漏等の鼻症状の出現 は頭痛や視器症状よりも少ないため, 当初, 眼科や神経 内科を受診し，蝶形骨洞炎が見落とされることがある91. 頭痛, 顔面痛, 眼䈑後部痛等が出現した場合や複視の訴 えがある場合には，鼻症状がなくとも蝶形骨洞炎を鑑別 疾患に挙げる必要があると考えられる10).

蝶形骨洞炎が疑われるようであれば，まず蝶形骨洞自

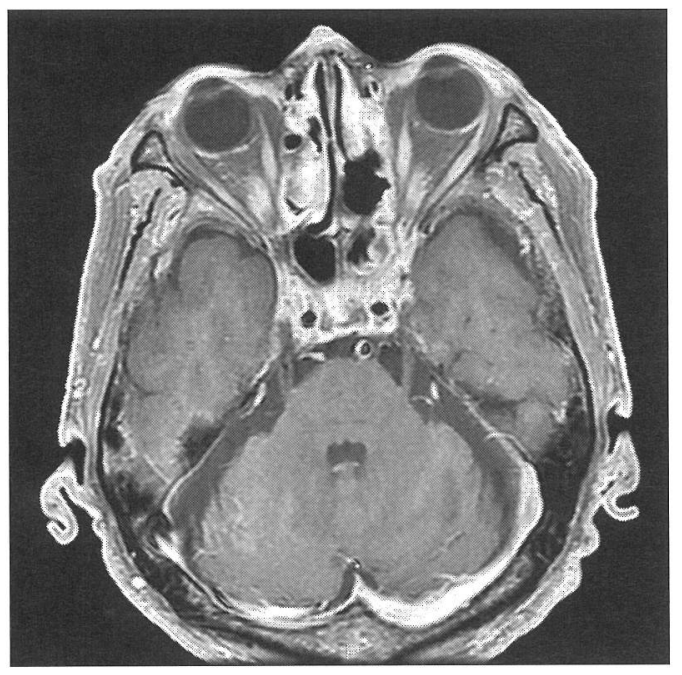

a

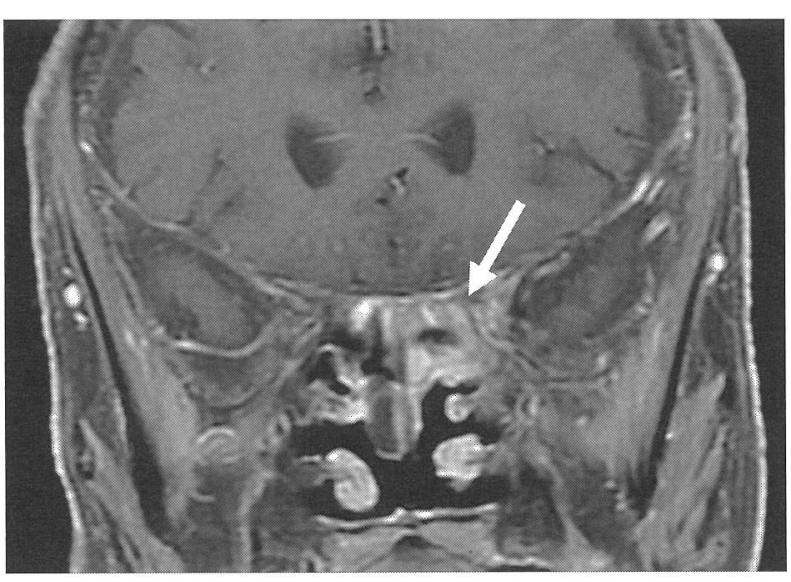

b

図 3 術後 MRI 所見（a. 軸位断，b. 冠状断） 海綿静脈洞付近にガドリニウム造影 $\mathrm{T} 1$ 強調画像で増強される炎症所見 $(\rightarrow)$ が認められる. 
然孔付近からの排膿の有無や鼻茸の有無を確認し，さら に CT や MRI での画像診断が必要である。蝶形骨洞炎発 症に関与する因子として, 蝶形骨洞隔壁の解剖学的バリ エーション, 蝶形骨洞自然孔の位置異常, 鼻中隔弯曲症, などが挙げられ6)，これらをチェックするのに画像診断 は有用である10).

治療に関しては，神経症状を合併した蝶形骨洞炎に対 して，早期の手術が必要であるとする報告が多い11122. 本症例では, 外転神経麻痺出現から当科受診までにすで に1週間経過していたため, 早急の手術加療を選択した。

外転神経麻痺の機序として，(1)蝶形骨洞の炎症が眼窩 内側壁を経由して波及する，(2)経静脈的に上眼窝裂付近 へ波及する，(3)蝶形骨洞から海綿静脈洞に波及する，と いう3 つの経路がある13). 本症例では MRI にて海綿静脈 洞付近に炎症性病変が確認されたため, 3 番目の経路が 考元られる。一般に発症 2 週間以内に手術が施行されれ ば，術後数カ月以内に治癒が期待できるとされており 2)14)15), 本症例でも術後 2 力月半後には麻痺は完全に回復 した．神経麻痺が出現してから手術までの期間も神経麻 痺回復の予後に影響するため, 蝶形骨洞炎に合併する神 経障害に対しては積極的に手術加療を施行すべきである と考えられた。 また患者は症状により眼科，神経内科な どさまざまな科を受診することが考えられるため，他科 との連携を密にして早期診断に努めることが重要である と思われる。

\section{まとめ}

外転神経麻痺を呈した蝶形骨洞炎の1症例を報告した。 発症より 7 日後に内視鏡下経篩骨洞的蝶形骨洞開放術を 施行し，術後 2 力月半で麻痺は全快した。 こうした症例 において良好な子後を得るには早期診断，早期治療が必 要であると考えられた。

\section{参考文献}

1）松本 秀, 中村光士郎, 黒川浩伸, 他：限局性蝶形骨洞病 変の検討. 耳鼻臨床 $91 ： 919 \sim 923,1998$.

2）里和一仁, 金子研吾, 飛田 正, 他 : 海綿静脈洞進展を認 めた 7 症例の検討. 日鼻科会誌 $41: 341 \sim 344,2002$.

3）笹森史朗, 渡邊敏明, 大和田健司, 他：動眼神経麻痺を主 症状とした後部副鼻腔囊胞の 1 症例. 耳鼻 - 頭頸外科 65 : $391 \sim 394,1993$.

4）三澤 清, 浅井美洋, 向高洋幸, 他 : 内直筋麻痺による複 視を呈した蝶形骨洞炎の 1 例. 耳鼻・頭頸外科 $73: 309 \sim$ $312,2001$.

5) Schor DI : Headache and facial pain-the role of the paranasal sinuses: a literature review. Cranio $11: 36 \sim 47,1993$.

6) Lawson $\mathrm{W}$ and Reino $\mathrm{AJ}$ : Isolated sphenoid sinus disease: an analysis of 132 cases. Laryngoscope 107:1590 1595, 1997.

7) Martin TJ, Smith TL, Smith MM, et al. : Evaluation and surgical management of isolated sphenoid sinus disease. Arch Otolaryngol Head Neck Surg 128 : $1413 \sim$ 1419, 2002.

8）鈴木秀明, 千葉敏彦, 高坂知節 : 原発性孤立性蝶形骨洞真 菌症の 1 症例. 耳鼻・頭頸外科 $64: 908 \sim 912,1992$.

9）長櫓 巧, 渡 雅文, 塚原悦子, 他：蝶形骨洞炎により強 い頭痛を起こした 1 症例. ペインクリニック 8:495〜 497, 1987.

10）山口宗一, 未野康平, 矢田修一郎, 他 : 孤立性蝶形骨洞炎 症例の検討. 耳鼻臨床 $99: 11 \sim 17,2006$.

11) Goldman GE, Fontanarosa PB and Anderson JM : Isolated sphenoid sinusitis. Am J Emerg Med $11: 235 \sim 238,1993$.

12）赤井畑喜久子, 小川 洋, 鹿野真人, 他: 蝶形骨洞真菌症 の 3 症例と文献的考察. 日鼻科会誌 $40: 304 \sim 311,2001$.

13）高橋利弥, 石川 健, 小野寺毅, 他：動眼神経麻痺をきた した蝶形骨洞炎の 1 例. 耳鼻・頭頸外科 $71: 119 \sim 121,1999$.

14）小原由紀子，佐竹充章 : 外転神経麻痺をきたした蝶形骨洞 炎の一例. 岩手病医会誌 $36: 27 \sim 29,1997$.

15）井口芳明, 小川克二, 山本一博, 他 : 視器障害を呈した蝶 形骨洞炎例. 耳鼻臨床 $90: 925 \sim 930,1997$.

原稿受付：平成19年 3 月 7 日 原稿採択：平成19年 6 月 27 日 別刷請求先 : 加藤明子 干807-0855 北九州市八幡西区医生ヶ丘1-1 産業医科大学医学部耳鼻咽喉科学教室 